\title{
Hydrolysis of the Leu-Gly Bond of Phenylazobenzyl- oxycarbonyl-L-Pro-L-Leu-Gly-L-Pro-D-Arg (a substrate of microbial collagenases) by Treponemes Isolated from the Subgingival Plaque of Periodontitis Patients
}

\author{
Kauko K. Mäkinen, Salam A. Syed, Sergio L. Salvador, and Pirkko-Liisa Mäkinen \\ Department of Biologic and Materials Sciences, School of Dentistry, The University of Michigan, Ann Arbor, Michigan, USA
}

\begin{abstract}
Cell extracts prepared from several oral treponemes isolated from the subgingival plaque of periodontitis patients showed high enzyme activity toward phenylazobenzyl-oxycarbonyl-L-prolyl-L-leucylglycyl-L-prolyl-D-arginine (a compound used as a substrate for microbial collagenases). One major enzyme hydrolyzing this substrate at the Leu-Gly bond only was partially purified from an unspeciated treponeme (strain US), Treponema denticola ATCC 35405 , and 29 different clinical isolates of $T$. denticola. The Treponema US enzyme also hydrolyzed furylacryloyl-L-leucylglycyl-L-prolyl-L-alanine (another substrate of bacterial collagenases) at the Leu-Gly bond. This enzyme also hydrolyzed various collagens and collagen-derived peptides. These treponemal proteases were sensitive to metal chelators and $p$-chloromercury compounds. The results indicate that human oral treponemes contain enzymes that readily hydrolyze in chromogenic protease substrates the Leu-Gly bond only that is the cleavage site of these substrates also by "true" microbial collagenases.
\end{abstract}

Several studies have demonstrated proteolytic activity in subgingival plaque $[1,3]$ and in specific microorganisms that are considered to be associated with periodontal disease $[5-13,15]$. Incubation of gingival fibroblasts in the presence of extracts from dental plaque caused drastic changes in the cells' appearance [7]. Such changes can be expected to result from bacterial hydrolytic activity. It is thus obvious that chronic exposure of the periodontal tissues to bacterial enzymes leads to chemical reactions that are harmful to the tissue. Of special interest are various endopeptidases, since they may attack tissue proteinaceous substances, releasing chemotactic or chemokinetic products that contribute to the maintenance of inflammatory conditions. We have previously employed a synthetic and soluble pentapeptide derivative as a substrate of endopeptides present in oral microorganisms [10, $11,13,14]$. This compound, phenylazobenzyloxycarbonyl-L-prolyl-L-leucylglycyl-L-prolyl-D-arginine (PZ-PLGPA), is hydrolyzed by "true" microbial collagenases and collagenolytic enzymes at the
Leu-Gly bond, and it has been suggested to be a suitable substrate for such enzymes $[2,10,18]$.

The purpose of this paper is to provide information about the presence of PZ-PLGPA-hydrolyzing enzymes in several organisms that have been claimed to be associated with periodontal disease. An enzyme that hydrolyzed the above pentapeptide derivative at the Leu-Gly bond only was demonstrated in 33 treponemes and in 5 other human oral microorganisms.

\section{Materials and Methods}

A medium-sized Treponema sp. (strain US) was isolated from the subgingival plaque of a periodontitis patient. The cells were maintained and cultivated in a tryptone-heart infusion-yeast extract broth containing $5 \%$ rabbit serum, as described earlier for $T$. denticola $[9,11]$. The harvesting and pretreatment of the cells, including their disintegration with ultrasound, were also described previously [9]. The source and cultivation of other treponemes [9, 11], the fusobacteria [9], Capnocytophaga [9], Bacillus cereus [10], B. gingivalis [9], and Streptococcus faecalis [14] were described in cited references. S. faecalis (human oral strain 0G1-10) was included in this study as a PZ-PLGPA-nega- 
Table 1. Ability of various oral microorganisms to hydrolyze PZ-PLGPA

\begin{tabular}{|c|c|}
\hline Organisms & Rate of hydrolysis ${ }^{b}$ \\
\hline Treponema denticola ATCC 35405 & 1.70 \\
\hline Myr & 1.25 \\
\hline $\operatorname{Sim}$ & 1.30 \\
\hline Corha & 1.70 \\
\hline$H_{1}$ & 1.05 \\
\hline Spira & 1.80 \\
\hline $\mathrm{Al}_{2}$ & 1.15 \\
\hline $\mathrm{H}_{22}$ & 1.15 \\
\hline T. vincentii ATCC 35580 & 1.53 \\
\hline$T$. (US) species & 0.89 \\
\hline T. socranskii & 0.20 \\
\hline$T$. denticola isolates & $2.3 \pm 0.6(n=22)$ \\
\hline Fusobacterium nucleatum (FN2) & 0.4 \\
\hline F. nucleatum (FN3) & 0.4 \\
\hline Capnocytophaga sp. & 0.5 \\
\hline Bacillus cereus & 2.5 \\
\hline B. gingivalis & 1.8 \\
\hline Streptococcus faecalis (OG1 10) & Nil \\
\hline
\end{tabular}

"The reactions were carried out in $50 \mathrm{mM}$ Tris- $\mathrm{HCl}, \mathrm{pH} 8.0$ (containing $0.1 \mathrm{mMCaCl}$ ), at $30^{\circ} \mathrm{C}$ and $0.6 \mathrm{mM}$ substrate concentration. The reactions were carried out with the supernatant fluids ( $10 \mathrm{~min}: 23,500 \mathrm{~g}$ ) of cell extracts made by ultrasonic treatment of washed cells.

${ }^{b}$ In $\mu \mathrm{mol} \min ^{-1} \mathrm{mg}{ }^{\prime}\left(\times 10^{3}\right)$.

tive reference organism (although its gelatinase readily hydrolyzes various soluble and insoluble collagens).

The endopeptidase activity was routinely determined with PZ-PLGPA as substrate [18]. The hydrolysis of the Leu-Gly bond of this substrate was ascertained as reported earlier [13]. with reversed-phase chromatography and amino acid analysis. The Cd-ninhydrin method of Doi et al. [4] was used to compare the rates of the hydrolysis of several synthetic and natural peptidase substrates. In these cases the assay mixtures consisted of $100 \mu$ l of substrate solution (or homogeneous suspension when the substance was insoluble) made in $50 \mathrm{mM}$ Tris- $\mathrm{HCl}, \mathrm{pH} 7.5(2$ $\mathrm{mg} / \mathrm{ml}$ ), and 5-10 $\mu \mathrm{l}$ of enzyme. After incubation, $0.4 \mathrm{ml}$ of ninhydrin reagent and $1.0 \mathrm{ml}$ of ethanol were added, followed by reading of the color intensities at $570 \mathrm{~nm}$. L-Leucine was used as a standard. The hydrolysis of $\mathrm{N}$-aminoacyl-2-naphthylamines (2NAs), $\quad N$ - $\alpha$-benzoyl-L-arginyl-2NA (BANA), $N \alpha$-benzoyl-Larginyl-p-niroaniline (BAPNA) and furylacryloyl (FA) derivatives was determined as described earlier $[11,12]$. Proteinase activity was in some cases also tested with azocoll, azocasein and elastin-orcein [11]. The kinetics of the enzyme from certain treponemes was studied as reported previously $[13,16,17]$.

The ability of the Treponema US enzyme to hydrolyze collagen was studied in a reaction mixture consisting of $5 \mathrm{mg}$ of Sigma \#4387 insoluble collagen (Classical Type I, from bovine achilles tendon) suspended in $1 \mathrm{ml}$ of $20 \mathrm{mM}$ Tris- $\mathrm{HCl}(\mathrm{pH} 7.5)$, and of about $0.1 \mu \mathrm{g}$ of enzyme. Mixtures in which either the enzyme or the collagen was omitted were included. The mixtures were incubated for $24 \mathrm{~h}$ at $30^{\circ} \mathrm{C}$, followed by filtration through 0.2 $\mu \mathrm{m}$ Acro LC 13 membranes (Gelman, Ann Arbor, Michigan). The filtrates were evaporated to dryness at room temperature, and each of the dry residues was dissolved in $20 \mu \mathrm{l}$ of water, 10$\mu \mathrm{l}$ aliquots of these soutions were mixed with $10 \mu \mathrm{l}$ of denaturing buffer, followed by treatment for $12 \mathrm{~min}$ in a boiling water bath. Of the resulting preparations, $1.0-\mu 1$ aliquots were subjected to PhastGel electrophoresis with the Pharmacia PhastSystem (8\%25\% gel; silver staining; Pharmacia, Uppsala, Sweden). Protein concentrations were determined by the Bradford method with Sigma bovine serum albumin as the standard protein [6]. The Pharmacia PhastSystem, including the Phastgels and SDS Buffer Strips, was also used to study the ability of the Treponema US enzyme to degrade other collagens (Table 3 ). The method was optimized for $8 \%-25 \%$ PhastGel gradient media and silver staining. SDS-PAGE was also used to study the hydrolysis of $\left[{ }^{3} \mathrm{H}\right]$ rat tail tendon collagen (New England Nuclear, Boston, Massachusetts) catalyzed by this enzyme

The complete FPLC unit was purchased from Pharmacia (Uppsala, Sweden). For this study the unit was equipped with Superose 6 and Superose 12 columns, a Mono Q anion exchange column, an arginyl-sepharose column, and a phenyl-superose column. The proteins were monitored at $280 \mathrm{~nm}$ or $214 \mathrm{~nm}$. Because of the rapidity of the FPLC separations, the unit was operated at $22^{\circ} \mathrm{C}$. The FPLC programs used were described below. Unless otherwise indicated, all chemicals were from Sigma (St. Louis, Missouri). The water used in the study was Milliporetreated and had a resistance of at least $18 \mathrm{M} \Omega \mathrm{cm}^{-1}$. The culture media were prepared from Difco Products (Detroit. Michigan).

\section{Results and Interpretations}

Ability of cell extracts to hydrolyze PZ-PLGPA. Cell extracts prepared by ultrasonic treatment of the cells were tested for proteinase activity with PZPLGPA as substrate (Table 1). All treponemes, the fusobacteria, Capnocytophaga, and the Bacillus species exhibited high PZ-PLGPA-hydrolyzing activity. The cell-free growth media obtained after removal of the cells showed high (extracellular) activity on PZ-PLGPA, especially in the case of $B$. cereus. The reference organism Streptococcus faecalis did not hydrolyze this substrate. A major PZ-PLGPA-hydrolyzing enzyme was thereafter partially purified from the medium-sized unspeciated treponeme (strain US), from Treponema denticola ATCC 35405, $T$. vincentii ATCC 35580, $T$. socranskii, from all $29 \mathrm{~T}$. denticola strains or clinical isolates listed in Table 1, and from Fusobacterium nucleatum (strain FN2). The purification procedure and results from partial characterization studies of the treponeme enzymes are summarized below. Unless separately mentioned, all procedures were performed in the cold $\left(+4^{\circ} \mathrm{C}\right)$. It was also established that the enzymes studied in this paper cleaved PZ-PLGPA at the Leu-Gly bond only [13].

PZ-PLGPA-hydrolyzing proteinase from Treponema US. The supernatant fluid of the cell extract ( $70 \mathrm{ml}$; resulting from a $1-\mathrm{L}$ culture) was dialyzed for $72 \mathrm{~h}$ against 200 volumes of $10 \mathrm{~m} M$ Tris- $\mathrm{HCl}$ (pH 7.0 , containing $1.0 \mathrm{mM} \mathrm{CaCl} 2$ ). The dialysate was 
centrifuged for $10 \mathrm{~min}$ at $23,500 \mathrm{~g}$ before being filtered through a $0.45-\mu \mathrm{m}$ Millipore filter for FPLC. The filtrate was injected into a Mono $\mathrm{Q}$ anion exchange column with a Superloop. The column was eluted with the above buffer at a flow rate of $1.0 \mathrm{ml}$ $\min ^{-1}$, applying a three-phase $\mathrm{NaCl}$ gradient shown in Fig. 1A. This FPLC program resulted in the appearance of one enzyme peak $(21-25 \mathrm{~min})$ with high activity toward PZ-PLGPA. The active fractions were pooled, and the pool was concentrated to $2 \mathrm{ml}$ with an Amicon Microconcentrator (cut-off 30,000 mol. wt.). Concentrated enzymes from three similar separations were combined for the next step.

The enzyme from the previous step was injected into a Superose 6 Prep column. One enzyme peak that showed activity toward PZ-PLGPA appeared (not shown). The active fractions were pooled $(15 \mathrm{ml})$, and the pool was dialyzed for $24 \mathrm{~h}$ against 1000 volumes of $3 \mathrm{~m} M$ Tris- $\mathrm{HCl}(\mathrm{pH} 7.5$, containing $0.3 \mathrm{mM} \mathrm{CaCl}$ ). The dialysate was applied on an arginyl-sepharose affinity column (1.0 $\mathrm{cm} \times 25 \mathrm{~cm})$ and eluted with the above buffer, which contained a linear $\mathrm{NaCl}$ gradient from zero to 1.0 $M$ (Fig. 1B). This separation resulted in the appearance of one PZ-PLGPA-hydrolyzing enzyme. The active fractions were pooled $(30 \mathrm{ml})$ and concentrated on an Amicon YM10 membrane to $2.0 \mathrm{ml}$. The development of the specific activity of the enzyme is shown in Table 2 . The molecular weight of the enzyme was estimated to be near 100,000 .

The PZ-PLGPA-hydrolyzing proteinase did not hydrolyze BANA, BAPNA, or N-aminoacyl-2NAs. The most rapidly hydrolyzed substrates were PZPLGPA and FA-Leu-Gly-Pro-Ala (FALGPA; Table 3 ), both of which have been used as substrates of microbial collagenases. Both were hydrolyzed at the Leu-Gly bond only. The following FA derivatives were not hyrolyzed: FA-Phe, FA-Phe-Phe, FA-Phe-Gly-Gly, FA-Ala-Phe- $\mathrm{NH}_{2}$, FA-Trp, FAGly-Leu-Ala- $\mathrm{NH}_{2}$ ), FA-Leu methyl ester, and FATrp methyl ester. Other substrates that were hydrolyzed included the soluble collagen digests (Sigma Polypep preparations), Type VI soluble collagen, and fibrinogen. Sigma \#4387 insoluble collagen (classical Type I; from bovine achilles tendon) was

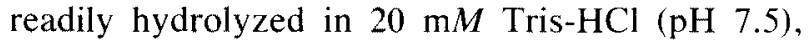
producing, in $20 \mathrm{~h}$ incubations, soluble fragments whose molecular weights ranged from 10,000 to 60,000 (not shown). ${ }^{3} \mathrm{H}$-labeled collagen was hydrolyzed as tested with the New England Nuclear collagenase assay kit. Figure 2 shows that the enzyme hydrolyzed PZ-PLGPA most rapidly at $\mathrm{pH} 7.5$. The enzyme was sensitive to all metal chelators tested

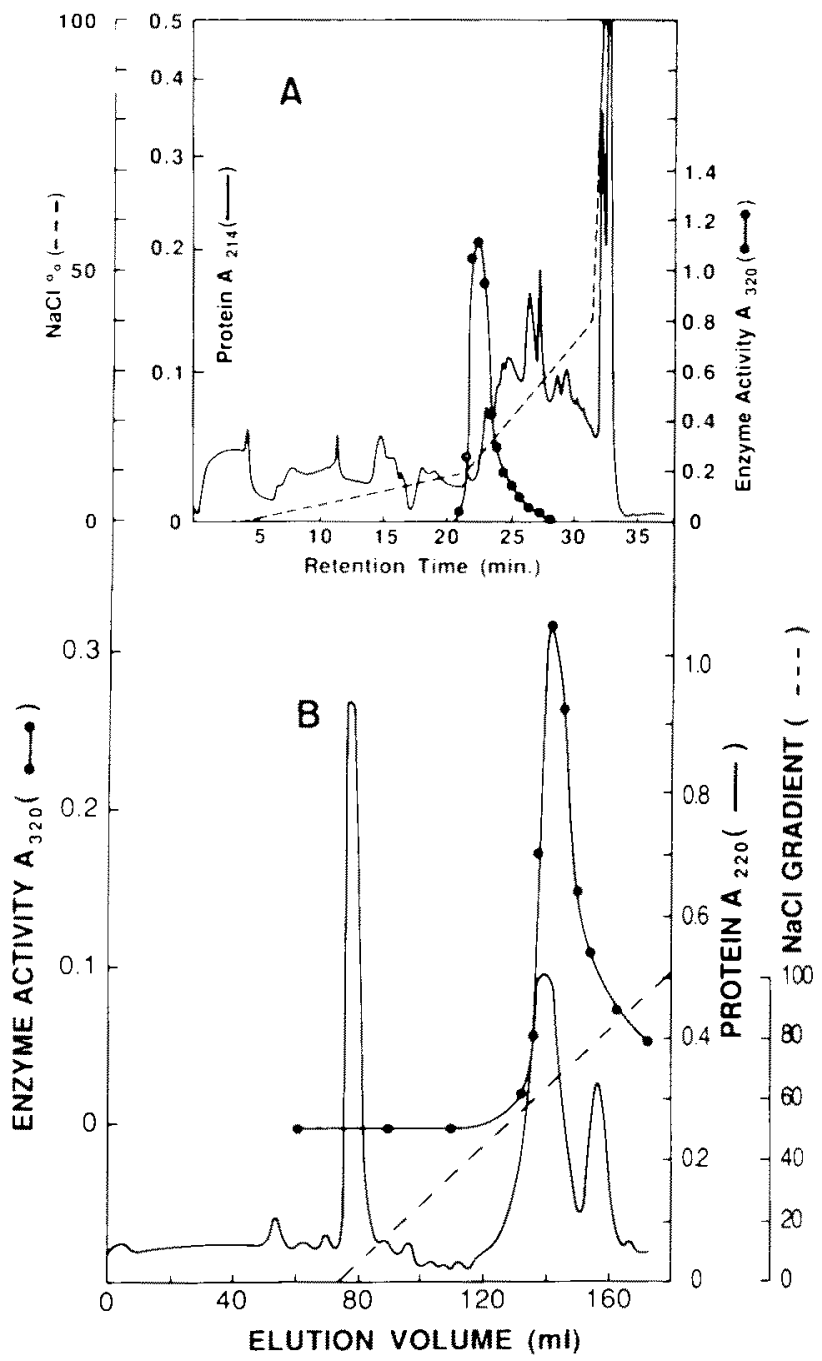

Fig. 1. Panel A: Separation by FPLC of a PZ-PLGPA-hydrolyzing proteinase from the cell extract of the unspeciated treponeme (strain US). Thoroughly dialyzed enzyme (supernatant fluid of cell sonicate) was injected into a Mono $Q$ anion exchange column that was equilibrated and eluted with $10 \mathrm{~m} M$ Tris- $\mathrm{HCl}(\mathrm{pH} 7.0$, containing $1.0 \mathrm{mM} \mathrm{CaCl}_{2}$ ). A three-step $\mathrm{NaCl}$ gradient was applied after all sample had entered the column (with a Superloop; at $4 \mathrm{~min}$ ). The active fractions $(21.5-23.5 \mathrm{~min}$ ) were pooled, and the pool was dialyzed for the subsequent gel permeation chromatography (see text). Panel B: Further purification of the PZPLGPA-hydrolyzing proteinase from the unspeciated treponeme (strain US) on an arginyl-sepharose column $(1 \mathrm{~cm} \times 25 \mathrm{~cm})$. A 6$\mathrm{ml}$ sample from the previous purification step (see text) was applied (a typical separation is shown), eluting the column with 3 $\mathrm{m} M$ Tris- $\mathrm{HCl}(\mathrm{pH} 7.5$, containing $0.3 \mathrm{mMCaCl}$ and a $\mathrm{NaCl}$ gradient from zero to $1.0 \mathrm{M}$ ). The active fractions were pooled and concentrated.

(Table 4). Because PCMPS (Table 4) was a strong inhibitor of the reaction, it is possible that the enzyme activity depended on an essential sulfhydryl residue. 
Table 2. Purification of the major PZ-PLGPA-hydrolyzing enzyme from medium-size Treponema US

\begin{tabular}{lcccc}
\hline Purification step & $\begin{array}{c}\text { Volume } \\
(\mathrm{ml})\end{array}$ & $\begin{array}{c}\text { Protein } \\
(\mathrm{mg} / \mathrm{ml})\end{array}$ & $\begin{array}{c}\text { Total } \\
\text { protein }(\mathrm{mg})\end{array}$ & $\begin{array}{c}\text { Specific activity } \\
\left(\mathrm{mmol} \mathrm{mg}^{-1} \mathrm{~min} \mathbf{1}^{-1}\right)\end{array}$ \\
\hline $\begin{array}{l}\text { Cell sonicate } \\
\quad \text { (after centrifugation) }\end{array}$ & 70 & 0.75 & 52.5 & 0.95 \\
$\begin{array}{l}\text { After Mono Q separations } \\
\text { and concentrations }\end{array}$ & 6 & 1.0 & 6.0 & 14.0 \\
$\begin{array}{l}\text { After Superose 6 gel } \\
\text { After affinity chromatography } \\
\quad \text { on arginyl-sepharose }\end{array}$ & 15 & 0.15 & 2.25 & 21.0 \\
\hline
\end{tabular}

Table 3. Ability ${ }^{a}$ of the Treponema strain US proteinase to hydrolyze various peptidase substrates in the presence of $\mathrm{Ca}^{2-}$ and without added $\mathrm{Ca}^{2-}$

\begin{tabular}{|c|c|c|}
\hline Substrate & $1 \mathrm{~m} M \mathrm{Ca}^{2-\cdots}$ & $\begin{array}{c}\text { No } \\
\text { No added } \\
\mathrm{Ca}^{2-}\end{array}$ \\
\hline PZ-PLGPA (Sigma) & 0.975 & 0.160 \\
\hline $\begin{array}{l}\text { Furylacryloyl-L-Leu-Gly-L-Pro-L- } \\
\text { Ala (Sigma) (FALGPA) }\end{array}$ & 0.822 & 0.816 \\
\hline $\begin{array}{l}\text { Furylacryloyl-Gly-Leu-Amide } \\
\text { (Sigma) }\end{array}$ & - & - \\
\hline BAPNA (Sigma) & - & - \\
\hline Polypep, low-viscosity (Sigma) ${ }^{b}$ & 0.0125 & 0.031 \\
\hline Polypep, high-viscosity (Sigma) ${ }^{b}$ & 0.0262 & 0.0187 \\
\hline $\begin{array}{l}\text { Collagen (Sigma \#7521; Type VI, } \\
\text { soluble, from human placenta) }\end{array}$ & 0.0162 & - \\
\hline Gelatin (Baker \& Adamson) & - & - \\
\hline $\begin{array}{l}\text { Fibrinogen (Mann; bovine, plas- } \\
\text { minogen-free) }\end{array}$ & 0.022 & 0.015 \\
\hline Serum albumin (Sigma; bovine) & - & - \\
\hline Casein (Calbiochem) & 0.005 & 0.004 \\
\hline Hemoglobin (Pierce) & - & - \\
\hline
\end{tabular}

In nmol $\mathrm{min}^{-1} \mathrm{mg}^{-1}$. The reactions were performed at $37^{\circ} \mathrm{C}$ in 50 $\mathrm{m} M$ Tris- $\mathrm{HCl}, \mathrm{pH} 7.8$, with a ninhydrin method $[4]$ to determine the liberation of free amino groups.

${ }^{b}$ Soluble collagen polypeptides (made by digestion). -, No activity detected.

PZ-PLGPA-hydrolyzing activity in Treponema denticola. An essentially similar purification procedure was used for the enzyme from $T$. denticola ATCC 35405 . The partially purified enzyme showed no activity toward azocasein, serum albumin, and the $\mathrm{N}$ aminoacyl-2NAs previously listed [13]. The enzyme was inhibited by $90 \%$ and $70 \%$ in the presence of $0.0167 \mathrm{~m} M$ EDTA and 1,10-phenantroline, respectively. p-Chloromercuribenzoic acid (PCMB) (1.67 $\mu M$ ) inhibited the enzyme totally, while $0.0167 \mathrm{mM}$ dithiothreitol had no effect. The enzyme hydrolyzed PZ-PLGPA most rapidly at $\mathrm{pH} 8.0$ in $0.1 \mathrm{M}$ phosphate buffer. The optimum $\mathrm{pH}$ values in 50 $\mathrm{m} M$ Tris- $\mathrm{HCl}$ and $50 \mathrm{~m} M$ borate buffers were 8.0 and 8.6, respectively. The hydrolysis of PZ-PLGPA displayed sigmoidal Michaelis curves and substrate inhibition. The latter started to appear above 0.46 $\mathrm{m} M$ substrate level. The enzyme was stable at $\mathrm{pH}$ $5.1(0.1 M$ phosphate buffer). The presence of a similar PZ-PLGPA-hydrolyzing enzyme was subsequently discovered and partially purified from all $T$. denticola strains or isolates mentioned in Table 1. The enzymes obtained from 17 of these isolates were subjected to characterization studies. The $\mathrm{pH}$ optimum of the hydrolysis of PZ-PLGPA by these enzymes in $50 \mathrm{~m} M$ Tris- $\mathrm{HCl}$ was near $\mathrm{pH} 7.5-8.0$; the enzyme from the isolate designated as \#62, however, showed the highest rate of hydrolysis at $\mathrm{pH}$ 7.0. The kinetics of the hydrolysis of PZPLGPA by these enzymes was not exactly identical, as evidenced by the distinctly different $\mathrm{K}_{m}$ values obtained (Fig. 3). The values shown were determined by the Hanes' plot, but similar values were obtained from the double reciprocal plot and the Hofstee plot (velocity versus $v /[S]$ ). Typical Michaelis kinetics was observed at [PZ-PLGPA] up to $0.62 \mathrm{~m} M$. The PZ-PLGPA-hydrolyzing enzymes from all 17 clinical isolates of $T$. denticola were sensitive to PCMB; $1.67 \mu \mathrm{M}$ inhibitor reduced the rate of the hydrolysis by $90 \%$ to $95 \%$, and even at 0.0167 $\mu M$ inhibitor level the inhibition was $10 \%-20 \%$. The enzymes were inhibited by $35 \%-75 \%$ in the presence of $0.0167 \mathrm{mM}$ 1,10-phenantroline, while EDTA at the same concentration inhibited by $80 \%$ $98 \%$. The thiols (Table 4 ) were tested at a high concentration; these results do not exclude the possible importance of an SH group for enzyme activity.

All treponemes studies in this paper contained at least one major enzyme capable of hydrolyzing PZ-PLGPA, a substrate used in the study of microbial collagenases and collagenolytic enzymes. The Treponema US enzyme hydrolyzed also FALGPA, various collagens, and collagen-derived peptides. A "true" bacterial collagenase degrades in the helical regions of the native collagen, preferentially the $\mathrm{X}$ - 


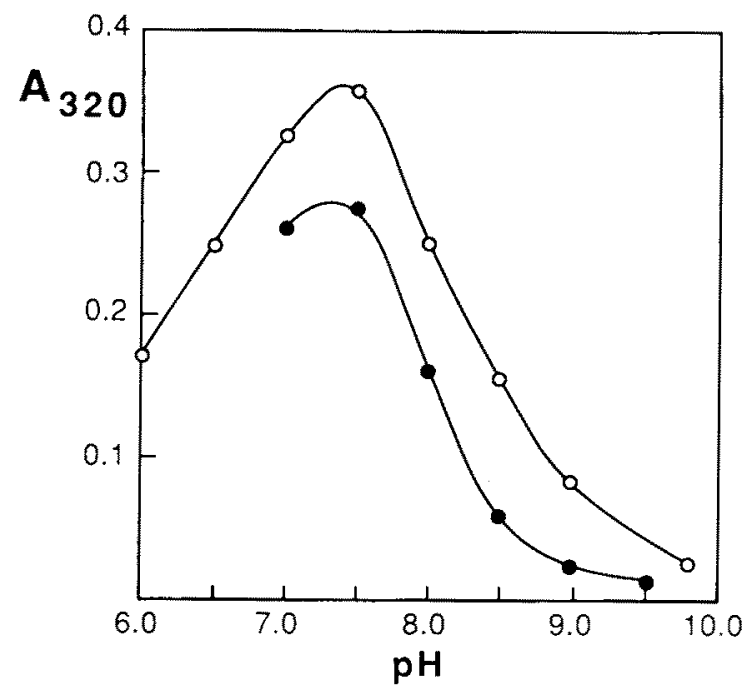

Fig. 2. Effect of $\mathrm{pH}$ on the rate of the hydrolysis of PZ-PLGPA catalyzed by the proteinase present in the unspeciated treponeme (strain US). The reactions were carried out in $0.1 \mathrm{M}$ Tris- $\mathrm{HCl}$ (open circles) and $0.05 \mathrm{M}$ phosphate buffers (closed circles), at $37^{\circ} \mathrm{C}$, with $0.5 \mathrm{mM}$ substrate concentration.

Gly bond. It is necessary to emphasize that the hydrolysis of the peptide of a composition similar to sequences existing in collagen, or the fact that the enzyme degrades collagen, is not sufficient evidence that a true collagenase is involved. However, the clinical significance of bacterial collagenolysis should not be belittled even if a "true" collagenase is not involved. Therefore, all bacterial enzyme activity that is directed toward insoluble and soluble collagens, synthetic model substrates, or stained collagen preparations (Azocoll) should be regarded as interesting from the pathological point of view. Furthermore, the criteria set for bacterial collagenases will undergo changes when all current information on substrate specificity is considered.

In spite of the obviously constitutive presence of the PZ-PLGPA-hydrolyzing enzymes in $T$. denticola, $T$. vincentii, and $T$. socranskii, the respective enzymes seem to differ as proteins. For example, the $T$. denticola enzyme has a higher molecular weight than the $T$. vincentii enzyme [13]. The fact that all enzymes were sensitive to metal chelators suggests that they may be metalloendopeptidases.

\section{Conclusions}

1. All of the 33 treponemes isolated from the subgingival plaque of periodontis patients displayed enzyme activity toward PZ-PLGPA, a substrate that has been used in the study of microbial col-

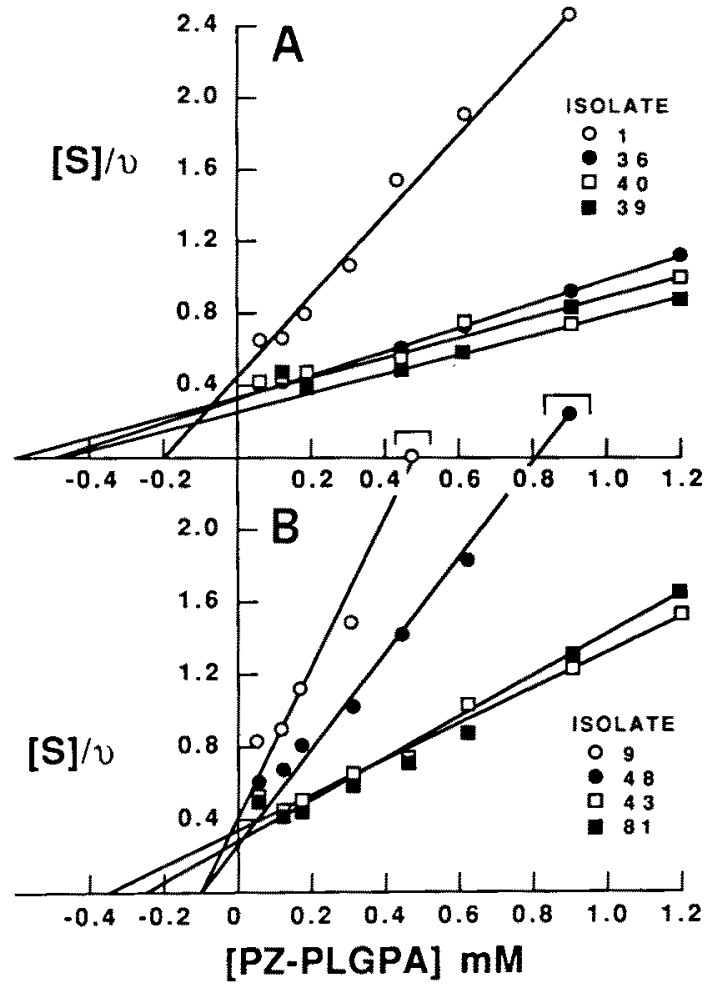

Fig. 3. Hanes' plot of substrate concentration divided by the initial velocity ([S]/v) versus the substrate concentration in the hydrolysis of PZ-PLGPA catalyzed by proteinases separated by FPLC from eight clinical isolates of Treponema denticola. The reactions were performed at $30^{\circ} \mathrm{C}$ in $50 \mathrm{mM}$ Tris- $\mathrm{HCl}, \mathrm{pH} 8.0$ (containing $0.01 \mathrm{mMCaCl}$ ). The values obtained for $\mathrm{K}_{\mathrm{m}}$ were 0.2 $\mathrm{m} M, 0.5 \mathrm{~m} M, 0.5 \mathrm{~m} M$, and $0.6 \mathrm{~m} M$ for enzymes $1,36,39$, and 40 . respectively (Panel A): and $0.1 \mathrm{~m} M, 0.1 \mathrm{mM}, 0.25 \mathrm{~m} M$ and 0.35 $\mathrm{m} M$ for enzymes $9,48,81$, and 43 , respectively (Panel B). The enzyme numbers given are those of the clinical isolates studied.

Table 4. Effect of various chemical reagents on the hydrolysis of PZ-PLGPA by the collagenolytic proteinase of the medium-size Treponema (strain US) ${ }^{a}$

\begin{tabular}{lc}
\multicolumn{1}{c}{ Reagent } & Inhibition $\%$ \\
\hline Chelators & \\
EDTA $(1.0 \mathrm{~m} M)$ & 97.6 \\
1,10-Phenantroline $(1.0 \mathrm{~m} M)$ & 94.3 \\
8-Hydroxyquinoline 5 -sulfonic acid $(1.0 \mathrm{mM})$ & 69.8 \\
EGTA $(1.0 \mathrm{~m} M)^{b}$ & 62.5 \\
Thiols: & \\
Dithiothreitol $(1.0 \mathrm{~m} M)$ & 51.8 \\
L-Cysteine $(1.0 \mathrm{mM})$ & 7.8 \\
PCMPS $5 \mu M$ & 86.3 \\
\multicolumn{10}{c}{$5 \mathrm{M}$} & 89.2 \\
$50 \mu M$ & 90.9 \\
\hline
\end{tabular}

a The reactions were carried out in $0.1 \mathrm{M}$ Tris $-\mathrm{HCl}, \mathrm{pH} 7.5$, with $0.5 \mathrm{~m} M$ PZ-PLGPA as substrate at $37^{\circ} \mathrm{C}$.

${ }^{b}$ Ethyleneglycol-bis-( $\beta$-aminoethyl ether) $\mathrm{N}, \mathrm{N}, \mathrm{N}^{\prime}, \mathrm{N}^{\prime}$-tetraacetic acid.

${ }^{c} p$-Chloromercuriphenylsulfonic acid (tested in $50 \mathrm{~m} M$ phosphate buffer, $\mathrm{pH} 7.5$ ). 
lagenases and collagenolytic enzymes. Fusobacteria, Capnocytophaga, and Bacillus species also exhibited this type of activity.

2. A major enzyme hydrolyzing PZ-PLGPA at the Leu-Gly bond only was partially purified from all the treponemes studied. The enzyme was inhibited by metal chelators and $p$-chloromercury compounds.

3. The major PZ-PLGPA-hydrolyzing enzyme from a medium-sized treponeme (US) cleaved various collagens and collagen-derived peptides, and also a furylacryloyl derivative (another substrate of collagenase-like bacterial enzymes) at the Leu-Gly bond only.

4. The preferential hydrolysis of the Leu-Gly bond in the above substrates and the hydrolysis of collagen by Treponema US suggests that a more detailed chemical study should be conducted on the relationship between the degradation of periodontal collagen and the human oral treponemes.

\section{Literature Cited}

1. Alfano MC, Morhart, RE, Metcalf G, Drummond JF (1974) Presence of collagenase from Clostridium histolyticum in gingival sulcal debris of a primitive population. Den Res $53: 142$

2. Bond MD, Van Wart HE (1984) Purification and separation of individual collagenases of Clostridium histolyticum using red dye ligand chromatography. Biochemistry 23:3077-3085

3. Bretz WA, Loesche WJ (1987) Characteristics of trypsin-like activity in subgingival plaque samples. J Dent Res 66:16681672

4. Doi E, Shibata D, Matoba T (1981). Modified colorimetric ninhydrin methods for peptidase assay. Anal Biochem 118:173-184
5. Fiehn N-E (1986) Enzyme activities from eight small-sized oral spirochetes. Scand J Dent Res 94:132-140

6. Kato T, Ono M, Ikawa M, Okuda K, Takazoe I (1984) Proteolytic activities of gram-negative bacteria isolated from human periodontal lesions. Jpn J Oral Biol 26:953-958

7. Larjava H. Jalkanen M. Penttinen R, Paunio K (1983) Enhanced synthesis of hyaluronic acid by human gingival fibroblast exposed to human dental bacterial extract. J Periodont Res 18:31-39

8. Laughon BE, Syed SA, Loesche WJ (1982) API ZYM system for identification of Bacteroides sp., Capnocytophaga $\mathrm{sp}$, and spirochetes of oral origin. J Clin Microbiol 15:97102

9. Loesche Wj, Syed SA, Schmidt E, Morrison EC (1985) Bacterial profiles of subgingival plaques in periodontis. J Periodontol 56:477-456

10. Mäkinen KK, Mäkinen P-L (1987) Purification and properties of an extracellular collagenolytic protease produced by the human oral bacterium Bacillus cereus (strain Soc 67), J Biol Chem 262:12488-12495

11. Mäkinen KK, Syed SA, Mäkinen P-L, Loesche WJ (1986) Benzoylarginine peptidase and iminopeptidase profiles of Treponema denticola strains isolated from the human periodontal pocket. Curr Microbiol. 14:85-89

12. Mäkinen KK. Syed SA. Mäkinen P-L. Loesche WJ (1987) Dominance of iminopeptidase activity in the human oral bacterium Trepenema denticola ATCC 35405. Curr Microbiol $14: 341-346$

13. Mäkinen KK. Syed SA, Loesche WJ, Mäkinen P-l, (1988) Proteolytic profile of Treponema vincentii ATCC 35580 with special reference to collagenolytic and arginine aminopeptidase activity. Oral Microbiol. Immunol 3:121-128

14. Mäkinen P-L, Clewell DB, An F, Mäkinen KK (1989) Purifcation and substrate specificity of a strongly hydrophobic extracellular metalloendopeptidase ("gelatinase") from Streptococcus faecalis (strain 0GI-10). J Biol Chem 264:3325-3334

15. Mayrand D, Grenier D. (1985) Detection of collagenase activity in oral bacteria. Can J Microbiol 31:134-138

16. Morihara K. Tsuzuki H (1970) Thermolysin: kinetic study with oligopeptides. Eur J Biochem 15:374-380

17. Segel I (1978) Enzyme kinetics. New York: Wiley, pp 64-71

18. Wünsch $E$, Heidrich HG (1963) Quantitative Bestimmung der Kollagenase. Z Physiol Chem 333:149-151 